\title{
Effective treatment of advanced solid tumors by the combination of arsenic trioxide and L-buthionine- sulfoximine
}

\author{
H Maeda $^{1,2,5}$, S Hori ${ }^{1}$, H Ohizumi ${ }^{1}$, T Segawa ${ }^{2}$, Y Kakehi ${ }^{3}$, \\ O Ogawa ${ }^{2}$ and A Kakizuka ${ }^{1,4, *}$ \\ ${ }^{1}$ Laboratory of Functional Biology, Kyoto University Graduate School of \\ Biostudies, Kyoto 606-8501, Japan; \\ 2 Department of Urology, Kyoto University Graduate School of Medicine, Kyoto \\ 606-8507, Japan; \\ ${ }^{3}$ Department of Urology, Kagawa Medical University, Kagawa 761-0793, \\ Japan; \\ 4 CREST, JST (Japan Science and Technology Corporation), Japan \\ ${ }^{5}$ Current address: Laboratory of Molecular Biology, NCl, NIH, Bethesda, MD \\ 20892-4264, USA \\ * Corresponding author: A Kakizuka, Kyoto University Graduate School of \\ Biostudies, Kyoto 606-8501, Japan; Tel: + 81-75-753-7675; \\ Fax: + 81-75-753-7676; E-mail: kakizuka@lif.kyoto-u.ac.jp
}

Received 22.7.03; revised 21.10.03; accepted 27.10.03; published online 5.3.04 Edited by $\mathrm{Dr} \mathrm{H}$ Ichijo

\begin{abstract}
Clinical application of anticancer agents has been often hampered by toxicity against normal cells, so the achievement of their cancer-specific action is still one of the major challenges to be addressed. Previously, we reported that arsenic trioxide $\left(\mathrm{As}_{2} \mathrm{O}_{3}\right)$ could be a promising new drug against not only leukemia but also solid tumors. The cytotoxicity of $\mathrm{As}_{2} \mathrm{O}_{3}$ occurred through the generation of reactive oxygen species (ROS), thus inhibiting radical scavenging systems would enhance the therapeutic efficacy of $\mathrm{As}_{2} \mathrm{O}_{3}$ provided that normal cells were relatively resistant to such a measure. Here, we report that the combination therapy of $\mathrm{As}_{2} \mathrm{O}_{3}$ with L-buthionine-sulfoximine (BSO), which inhibits a critical step in glutathione synthesis, effectively enhanced in vitro growth inhibition effect of $\mathrm{As}_{2} \mathrm{O}_{3}$ on all 11 investigated cell lines arising from prostate, breast, lung, colon, cervix, bladder, and kidney cancers, compared with $\mathrm{As}_{2} \mathrm{O}_{3}$ treatment alone. Furthermore, this combination enhanced cytotoxicity to cell lines from prostate cancer with less toxicity to those from normal prostate. In vitro cytotoxic assay using ROSrelated compounds demonstrated that hydrogen peroxide $\left(\mathrm{H}_{2} \mathrm{O}_{2}\right)$ is a major cytotoxic mediator among ROS molecules. Biochemical analysis showed that combined use of $\mathrm{As}_{2} \mathrm{O}_{3}$ and BSO blocked $\mathrm{H}_{2} \mathrm{O}_{2}$-scavenging systems including glutathione, catalase, and glutathione peroxidase, and that the degree of this blockade was well correlated with intracellular ROS levels and sensitivity to this treatment. Finally, the effectiveness of the combination therapy of $\mathrm{As}_{2} \mathrm{O}_{3}$ with BSO was demonstrated with an orthotopic model of prostate cancer metastasis. We propose that the combination therapy of $\mathrm{As}_{2} \mathrm{O}_{3}$ with $\mathrm{BSO}$ is a valid means of blockade of $\mathrm{H}_{2} \mathrm{O}_{2}$-scavenging system, and that the combination of a ROS-
\end{abstract}

generating agent with an inhibitor of major scavenging systems is effective in terms of both efficacy and selectivity. Furthermore, because the effective doses of both compounds are within clinically achievable range, this report will lead to immediate benefit for the development of a new cancer therapy.

Cell Death and Differentiation (2004) 11, 737-746.

doi:10.1038/sj.cdd.4401389

Published online 5 March 2004

Keywords: arsenic trioxide; buthionine-sulfoximine; advanced prostate cancer; hydrogen peroxide; orthotopic model

Abbreviations: $\mathrm{As}_{2} \mathrm{O}_{3}$, arsenic trioxide; $\mathrm{ROS}$, reactive oxygen species; $\mathrm{H}_{2} \mathrm{O}_{2}$, hydrogen peroxide; $\mathrm{BSO}$, L-buthionine-sulfoximine; GSH, glutathione; L-PAM, melphalan; SCID, severe combined immunodeficient; CDDP, cis-diaminodichloro-platinum; DOX, doxorubicin; NAC, $N$-acetyl-L-cysteine; DTT, dithiothreitol; SOD, superoxide dismutase; carboxy-PTIO, 2-(4-carboxyphenyl)-4,4,5,5tetramethylimidazoline-1-oxyl-3-oxide; LLC, Lewis lung carcinoma; WST-8, 2-(2-methoxy-4-nitrophenyl)-3-(4-nitrophenyl)-5-(2,4-disulfophenyl)-2H-tetrazolium monosodium salt; $\mathrm{CM}-\mathrm{H}_{2} \mathrm{DCFDA}$, 5-(and6)-chloromethyl-2', $7^{\prime}$-dichlorodihydrofluorescein diacetate; DTNB, 5,5'-dithiobis (2-nitrobenzoic acid; GPX, GSH peroxidase; GST, GSH-S-transferase; TUNEL, terminal deoxynucleotidyl transferasemediated nucleotide nick-end labeling

\section{Introduction}

One of the primary issues for cancer chemotherapy is how to kill cancer cells selectively without damaging normal cells. Experimentally, the selective cell death is partly achieved through various approaches. ${ }^{1-2}$ Clinically, however, poor selectivity of anticancer drugs can cause damage to normal cells, resulting in severe side effects, and thus limits their clinical efficacy. To treat advanced cancers with fewer side effects, oncologists have empirically developed many protocols of combination chemotherapy. Although some are effective, the majority is not. As a result, most advanced cancers, especially solid tumors, are not curable yet. Androgen-independent prostate cancer is one of the most frequently observed advanced solid tumors, the second cause of male cancer death in the US. Most forms of prostate cancer initially are androgen-dependent, but they soon become androgen-independent and thus their response to androgen ablation therapy is transient. Then, after a few years, the majority of prostate cancers relapse, on which no more effective therapies are available, resulting in cancer death. Despite the profound trials of various therapeutic approaches including combination chemotherapy, none has provided a marked survival advantage for patients in the 
androgen-independent stage of prostate cancer. Therefore, novel therapeutic strategies for androgen-independent prostate cancer are urgently needed.

Arsenic trioxide $\left(\mathrm{As}_{2} \mathrm{O}_{3}\right)$ has been used as an anticancer agent in traditional Chinese medicine for several thousand years and has recently been shown to induce clinical remission in patients with acute promyelocytic leukemia. ${ }^{3}$ We previously tested the effect of $\mathrm{As}_{2} \mathrm{O}_{3}$, targeting in advanced solid tumors, using androgen-independent prostate cancer as a cellular model. We showed that, at clinically achievable concentrations $(<2 \mu \mathrm{M}), \mathrm{As}_{2} \mathrm{O}_{3}$ inhibited in vitro cell growth and, at high concentrations, induced apoptosis in all cell lines derived from androgen-independent primary tumor growth in the prostate but also a high incidence of metastasis to the lymph nodes, the major target of metastasis in clinical cancers. In vivo analysis revealed that $\mathrm{As}_{2} \mathrm{O}_{3}$ induced tumor growth inhibition in orthotopic and metastatic lesions from this mouse orthotopic metastasis model. ${ }^{4}$ These findings provide evidence for the use of $\mathrm{As}_{2} \mathrm{O}_{3}$ as a novel and promising method to treat advanced solid tumors.

Chen et al. ${ }^{5}$ reported that $\mathrm{As}_{2} \mathrm{O}_{3}$ induced apoptosis in acute promyelocytic leukemia cells. Our previous study showed that the generation of reactive oxygen species (ROS) plays a major role in $\mathrm{As}_{2} \mathrm{O}_{3}$-induced cell death. ${ }^{4} \mathrm{ROS}$ such as hydrogen peroxide $\left(\mathrm{H}_{2} \mathrm{O}_{2}\right)$, superoxide, hydroxyl radicals, and nitrogen oxide are inevitably generated through the respiratory chain of mitochondria in even healthy tissues, but scavenged by the antioxidant defense system. ${ }^{6}$ Due to the recent advances in the understanding of $\mathrm{As}_{2} \mathrm{O}_{3}$-induced cell death and the ROS metabolism, it is possible to design a new combination chemotherapy based on these mechanisms.

We show here that L-buthionine-sulfoximine (BSO), a drug that depletes intracellular glutathione (GSH) and generates $\mathrm{ROS}$, is an effective sensitizer of $\mathrm{As}_{2} \mathrm{O}_{3}$-induced cell death. GSH is a major nonprotein thiol that has diverse functions including protection against oxidative stress, detoxification of xenobiotics, and bioreductive reactions. ${ }^{7}$ Historically, GSH depletion was believed to sensitize cells to anticancer treatment, and BSO was developed as an anticancer drug candidate that depletes GSH by inhibiting $\gamma$-glutamyl-cysteine synthetase, a rate-limiting enzyme of GSH synthesis. ${ }^{7}$ However, the combination of BSO with melphalan (L-PAM), an alkylating anticancer agent, has not shown any remarkable therapeutic effect on advanced solid tumors. ${ }^{7,8}$

In this study, we tested in vitro and in vivo efficacies of the combination therapy of $\mathrm{As}_{2} \mathrm{O}_{3}$ with $\mathrm{BSO}$ on androgenindependent prostate cancer cell lines as a model for advanced solid tumors.

\section{Results}

\section{Sensitization by BSO and antagonism by antioxidants on $\mathrm{As}_{2} \mathrm{O}_{3}$-induced inhibition of cell growth}

We first evaluated in vitro cell growth inhibition induced by $\mathrm{As}_{2} \mathrm{O}_{3}$ and BSO. In PC-3 cells, an androgen-independent prostate cancer cell line, the clinically obtainable concentration of $2 \mu \mathrm{M} \mathrm{As}_{2} \mathrm{O}_{3}$ inhibited cell growth in vitro to $55 \pm 3 \%$ of the vehicle-treated control (Figure 1A). Although $100 \mu \mathrm{M}$ BSO alone caused neither growth inhibition nor cell death (data not shown), BSO caused sensitization of $\mathrm{As}_{2} \mathrm{O}_{3}$-induced growth inhibition, and this effect is enhanced in a dose-dependent manner (Figure 1A). Addition of $\mathrm{N}$-acetyl-L-cysteine (NAC), an antioxidant that functions as a nonspecific scavenger of ROS, to $\mathrm{As}_{2} \mathrm{O}_{3} / \mathrm{BSO}$-treated cells dose dependently antagonized this sensitization (Figure $1 \mathrm{~B}$ ). We obtained essentially the same results with dithiothreitol (DTT), another antioxidant, and using DU145 cells, another androgen-independent prostate cancer cell line (Table 1). Further examinations extended these results to other solid tumor cell lines originating from breast, lung, colon, and cervix cancers (Table 1). In all of examined solid tumor cell lines, addition of $10 \mu \mathrm{M}$ BSO reduced $\mathrm{IC}_{50}$ values of $\mathrm{As}_{2} \mathrm{O}_{3}$ to less than $1 \mu \mathrm{M}$ (Table 1). It is noteworthy that this concentration is already known to be clinically achievable without significant side effects. $^{3}$

Acquired drug resistance is one of the most serious problems in cancer chemotherapy. We thus next investigated sensitization by BSO in drug-resistant cell lines. ${ }^{9,10} \mathrm{ACHN}$ CDDP and 5637-DR50 cells showed a 27.5- and 29.0-fold increase in mean $\mathrm{IC}_{50}$ values compared to parental $\mathrm{ACHN}$ and 5637 cells when treated with cis-diaminodichloro-platinum (CDDP) and doxorubicin (DOX), respectively (Table 1). These two cell lines appeared to have mild crossresistance to $\mathrm{As}_{2} \mathrm{O}_{3}, 1.6-2.1$-fold increase in $\mathrm{IC}_{50}$ values of $\mathrm{As}_{2} \mathrm{O}_{3}$ (Table 1). However, addition of $10 \mu \mathrm{M}$ BSO decreased $\mathrm{IC}_{50}$ values of $\mathrm{As}_{2} \mathrm{O}_{3}$ on these drug-resistant cell lines to less than $1 \mu \mathrm{M}$ (Table 1). This finding suggests that BSO sensitization on $\mathrm{As}_{2} \mathrm{O}_{3}$ cytotoxicity is effective not only to naive drug-sensitive cancer cells but also to drug-resistant cancer cells, typically observed in the relapsed case, at clinically achievable concentrations of both drugs. BSO has already been clinically used as a potential sensitizer of L-PAM, an alkylating anticancer agent. ${ }^{7,8}$ In our examination, the $I_{50}$ values of LPAM on PC-3 and DU145 cells were 105.0 \pm 18.0 and $9.9 \pm 2.3 \mu \mathrm{M}$, respectively. Addition of $10 \mu \mathrm{M}$ BSO decreased these $I_{50}$ values of L-PAM by 1.4- and 1.6-fold in PC-3 and DU145 cells, respectively. In contrast, when PC-3 and DU145 cells were sensitized with $\mathrm{BSO}$, the $\mathrm{IC}_{50}$ values of $\mathrm{As}_{2} \mathrm{O}_{3}$ decreased by 10.7- to 12.0-fold, respectively (Table 1). BSO always sensitized $\mathrm{As}_{2} \mathrm{O}_{3}$-induced cell toxicity more effectively than that induced by L-PAM in other solid tumor-derived cell lines including drug-resistant ones (data not shown). These results provide clear evidence that $\mathrm{BSO}$ sensitized $\mathrm{As}_{2} \mathrm{O}_{3}$ more strongly than L-PAM in many type of solid tumors including drug-resistant ones.

\section{Cell death phenotypes induced by $\mathrm{As}_{2} \mathrm{O}_{3}$ and $\mathrm{BSO}$}

We next investigated cellular morphology of PC-3 cells during $\mathrm{As}_{2} \mathrm{O}_{3}$-induced cell death in PC-3 cells under fluorescent microscopy (Figure $1 \mathrm{C}$ ). In PC-3 cells treated with $2 \mu \mathrm{M}$ $\mathrm{As}_{2} \mathrm{O}_{3}$, Hoechst 33342 staining showed large, oval nuclear shape typically seen in G2/M phase, whereas simultaneous rhodamine 123 staining demonstrated intact mitochondrial transmembrane potential (Figure $1 \mathrm{Cb}, \mathrm{g}$ ). Accumulation at G2/M phase was confirmed by flow cytometry using propidium-iodide (data not shown). BSO alone did not induce any morphological change (Figure $1 \mathrm{Cc}, \mathrm{h}$ ), but the combination of 
A

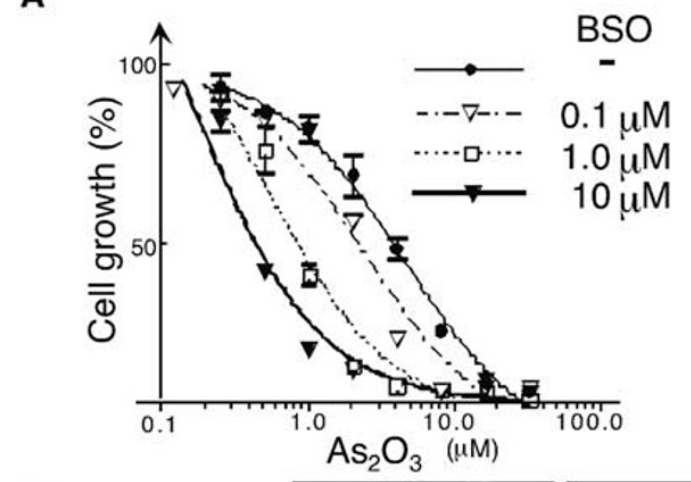

B
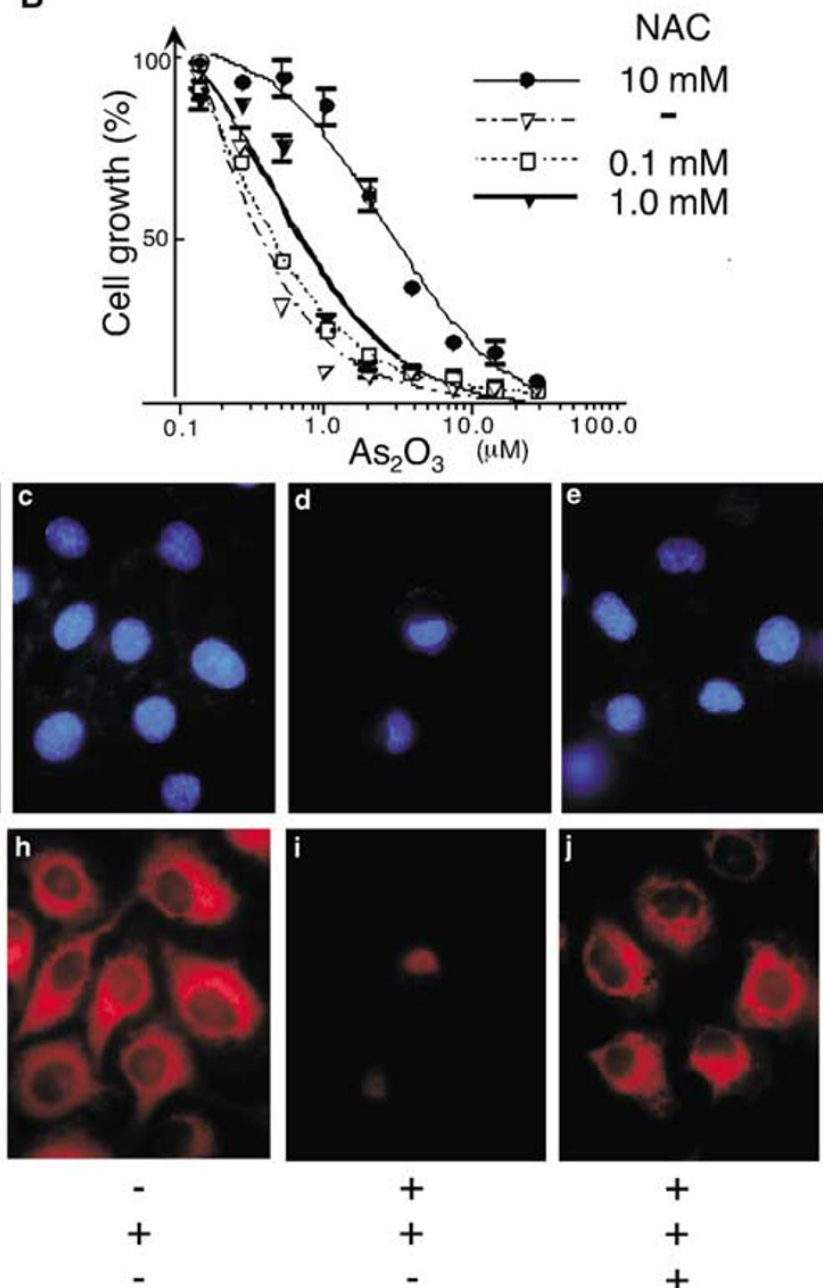

+
+
+

BSO

NAC

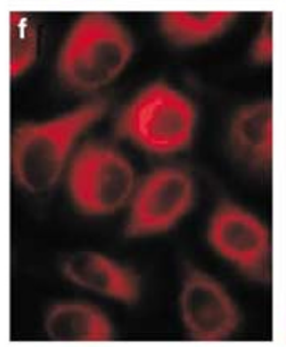

$-$
$+$

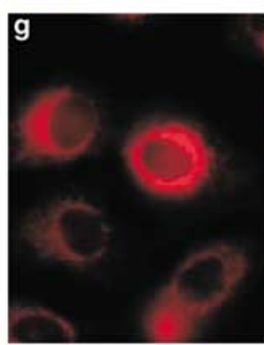

$-$

Figure 1 In vitro growth inhibition and apoptosis through the generation of ROS in combination with $\mathrm{As}_{2} \mathrm{O}_{3}$ and $\mathrm{BSO}$. (A) PC-3 cells were treated with various concentrations of $\mathrm{As}_{2} \mathrm{O}_{3}$ and $\mathrm{BSO}$ and incubated for $48 \mathrm{~h}$ prior to subjecting them to a growth inhibition assay using WST-8, a tetrazolium salt. Results are given as the means \pm S.D. of three independent experiments, the value of control being $100 \% . \mathrm{As}_{2} \mathrm{O}_{3}$ alone, plus $0.1 \mu \mathrm{M} \mathrm{BSO}$, plus $1 \mu \mathrm{M} \mathrm{BSO}$ and plus $10 \mu \mathrm{M} \mathrm{BSO}$. (B) PC-3 cells underwent the growth inhibition assay as described above following pretreatment with NAC. $\mathrm{As}_{2} \mathrm{O}_{3}$ and $10 \mu \mathrm{M} \mathrm{BSO}$, plus $0.1 \mathrm{mM} \mathrm{NAC,} \mathrm{plus} 1 \mathrm{mM}$ NAC and plus $10 \mathrm{mM}$ NAC. (C) PC-3 cells treated with indicated concentrations of $\mathrm{As}_{2} \mathrm{O}_{3}, \mathrm{BSO}$, and NAC for $36 \mathrm{~h}$ were stained with Hoechst $33342(1 \mu \mathrm{g} / \mathrm{ml}$, a-e) or the potential-sensitive probe rhodamine $123(10 \mu \mathrm{g} / \mathrm{ml}, \mathrm{f}-\mathrm{j})$ to make the nuclear morphology and mitochondrial membrane potential visible; (a and f) untreated; $\left(\mathrm{b}\right.$ and g) $2 \mu \mathrm{M} \mathrm{As} \mathrm{O}_{3} ;(\mathrm{c}$ and h) $10 \mu \mathrm{M}$ BSO; (d and i) $2 \mu \mathrm{M} \mathrm{As}{ }_{2} \mathrm{O}_{3}$ plus $10 \mu \mathrm{M} \mathrm{BSO}$; (e and j) $2 \mu \mathrm{M} \mathrm{As}{ }_{2} \mathrm{O}_{3}, 10 \mu \mathrm{M}$ BSO plus $10 \mathrm{mM} \mathrm{NAC}$

$2 \mu \mathrm{M} \mathrm{As}{ }_{2} \mathrm{O}_{3}$ and $10 \mu \mathrm{M}$ BSO induced morphological changes characteristic of apoptosis. Hoechst 33342 staining showed nuclear shrinkage (Figure $1 \mathrm{Cd}$ ) or chromatin condensation, especially in cells floating in the medium (data not shown). Simultaneous rhodamine 123 staining detected reduced mitochondrial transmembrane potential, which is commonly observed in apoptosis (Figure $1 \mathrm{Ci}$ ). Treatment of cells with NAC, an antioxidant known to scavenge ROS, antagonized $\mathrm{As}_{2} \mathrm{O}_{3} / \mathrm{BSO}$-induced apoptosis (Figure $1 \mathrm{Ce}, \mathrm{j}$ ). Quantification of DNA by flow cytometry confirmed these microscopic findings (data not shown). We obtained similar results from other solid tumor cell lines examined (data not shown). These results indicated that $\mathrm{BSO}$, through the generation of $\mathrm{ROS}$, sensitized cells to $\mathrm{As}_{2} \mathrm{O}_{3}$-induced cell death as illustrated typically by apoptotic morphology at clinically achievable concentrations of $\mathrm{As}_{2} \mathrm{O}_{3}$.

\section{Different sensitivity between normal and cancerous prostate cells at clinically obtainable concentrations of $\mathrm{As}_{2} \mathrm{O}_{3}$ and $\mathrm{BSO}$}

We next examined the selectivity of the combined treatment of $\mathrm{As}_{2} \mathrm{O}_{3}$ and $\mathrm{BSO}$ to cancer cells using a variety of malignant cancer cells and normal prostate-derived cells. In in vitro growth inhibition assays, $\mathrm{IC}_{50}$ values of $\mathrm{As}_{2} \mathrm{O}_{3}$ on $\mathrm{PrEC}$ and PrSC cells from normal prostate were $12.1 \pm 1.4$ and $12.0 \pm 4.9 \mu \mathrm{M}$, respectively (Table 1 ). These essentially identical values were approximately 1.9- to 5.5-fold higher than those of PC-3 and DU145 cells, androgen-independent prostate cancer cell lines (Table 1). In vitro cytotoxic assays showed a marked difference in $\mathrm{As}_{2} \mathrm{O}_{3}$-induced cytotoxicity between PrSC, PrEC, and PC-3 cells, but all cells were resistant to $\mathrm{As}_{2} \mathrm{O}_{3}$ at levels within the clinically achievable 
Table $1 \mathrm{IC}_{50}$ values of $\mathrm{As}_{2} \mathrm{O}_{3}$ in in vitro growth inhibition assays in solid cancer cell lines

\begin{tabular}{|c|c|c|c|c|c|c|}
\hline \multicolumn{7}{|l|}{ Treatments } \\
\hline $\mathrm{As}_{2} \mathrm{O}_{3}$ & + & + & + & + & + & + \\
\hline $\mathrm{BSO}(\mu \mathrm{M})$ & - & 0.1 & 1.0 & 10 & 10 & 10 \\
\hline NAC $10 \mathrm{mM}$ & - & - & - & - & + & - \\
\hline DTT $1 \mathrm{mM}$ & - & - & - & - & - & + \\
\hline \multicolumn{7}{|l|}{ Cell lines (origin) } \\
\hline PrEC (prostate) & $12.1(1.4)$ & $7.1(0.4)$ & $6.1(0.4)$ & $2.7(0.3)$ & $5.9(1.2)$ & $5.5(1.3)$ \\
\hline PrSC (prostate) & $12.0(4.9)$ & $8.8(2.8)$ & $1.8(0.7)$ & $0.63(0.1)$ & $12.4(4.4)$ & $5.9(0.8)$ \\
\hline PC-3 (prostate) & $2.4(0.3)$ & $1.2(0.2)$ & $0.37(0.1)$ & $0.20(0.3)$ & $0.72(0.07)$ & $1.2(0.2)$ \\
\hline DU145 (prostate) & $6.2(1.4)$ & $3.9(0.8)$ & $1.4(0.3)$ & $0.58(0.3)$ & $2.2(0.2)$ & $1.3(0.3)$ \\
\hline TSU-PR1 (bladder ${ }^{\mathrm{a}}$ ) & $2.2(0.3)$ & $1.9(0.2)$ & $1.0(0.1)$ & $0.18(0.3)$ & $0.82(0.3)$ & $1.1(0.3)$ \\
\hline SC115 (breast) & $4.8(1.4)$ & $2.3(0.4)$ & $0.63(0.12)$ & $0.30(0.04)$ & $1.3(0.23)$ & $1.5(0.2)$ \\
\hline LLC (lung) & $6.8(1.2)$ & $2.7(0.8)$ & $1.1(0.3)$ & $0.55(0.09)$ & $2.8(0.6)$ & $2.5(0.5)$ \\
\hline HCT15 (colon) & $11.0(1.0)$ & $7.3(0.3)$ & $2.9(0.1)$ & $0.83(0.06)$ & $10.3(2.9)$ & $8.3(0.6)$ \\
\hline HeLa (cervix) & $1.9(0.2)$ & $1.3(0.1)$ & $0.39(0.09)$ & $0.25(0.05)$ & $0.81(0.17)$ & $1.1(0.1)$ \\
\hline ACHN (kidney) & $13.7(2.3)$ & $7.7(1.3)$ & $1.5(0.2)$ & $0.43(0.06)$ & $5.1(1.8)$ & $3.6(0.7)$ \\
\hline ACHN-CDDP (kidney) & $21.7(2.1)$ & $14.0(1.7)$ & $5.3(0.6)$ & $0.93(0.25)$ & $18.0(2.0)$ & $7.5(0.5)$ \\
\hline 5637 (bladder) & $2.1(0.4)$ & $0.87(0.06)$ & $0.22(0.02)$ & $0.040(0.01)$ & $2.4(1.5)$ & $1.2(0.3)$ \\
\hline 5637-DR50 (bladder) & $4.4(0.6)$ & $1.4(0.2)$ & $0.23(0.03)$ & $0.097(0.01)$ & $2.7(1.2)$ & $2.2(1.3)$ \\
\hline
\end{tabular}

ACHN-CDDP and 5637-DR50 cells are 27.5- and 29.0-fold more resistant to CDDP and DOX, respectively, compared with each parental cell line. ${ }^{\text {a }}$ TSU-PR1 is considered to have arisen from androgen-independent prostate cancer. Data are expressed as the mean (standard deviation) of three independent experiments in triplicate.

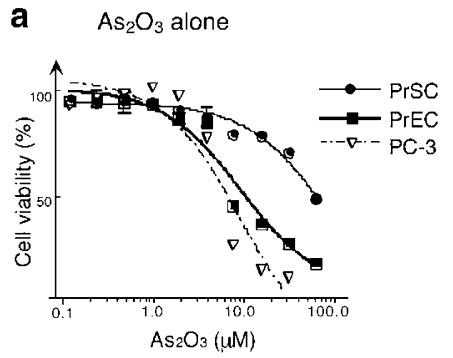

b $\quad \mathrm{As}_{2} \mathrm{O}_{3}+10 \mu \mathrm{MBSO}$

Figure 2 In vitro cytotoxicity of $\mathrm{As}_{2} \mathrm{O}_{3}$ plus $\mathrm{BSO}$ to cancer cells at clinically obtainable concentrations. In vitro cytotoxic assay using WST-8 as the substrate was carried out in triplicate in PrSC, PrEC, and PC-3 cells after $96 \mathrm{~h}$ incubation with various concentrations of $\mathrm{As}_{2} \mathrm{O}_{3}$ alone (a) or $\mathrm{As}_{2} \mathrm{O}_{3}$ plus $10 \mu \mathrm{M} \mathrm{BSO}$ (b). Results are given as the means \pm S.D. of three independent experiments, the value of vehicle-treated control being $100 \%$

concentrations, $<2 \mu \mathrm{M}$ (Figure 2a). However, the combination of $\mathrm{As}_{2} \mathrm{O}_{3}$ with $\mathrm{BSO}$ successfully decreased the cytotoxic $\mathrm{As}_{2} \mathrm{O}_{3}$ concentrations. The effect is more drastic on cancer-derived PC-3 cells than on normal prostate-derived PrSC and PrEC cells. More than $70 \%$ of PC-3 cells but less than $20 \%$ of PrEC cells and less than $5 \%$ of PrSC cells were killed by $1 \mu \mathrm{M} \mathrm{As}{ }_{2} \mathrm{O}_{3}$ together with $10 \mu \mathrm{M}$ BSO, which is within the clinically achievable range (Figure $2 b$ ). These findings indicated that, at clinically obtainable concentrations of the two drugs, an effective combination therapy on prostate cancers can be developed with minimal damage to normal cells.

\section{Intracellular levels of ROS as a determinant of cell death}

We next examined the relationship between the level of ROS and the cytotoxic effect of $\mathrm{As}_{2} \mathrm{O}_{3}$ using $\mathrm{CM}-\mathrm{H}_{2}$ DCFDA (5(and-6)-chloromethyl-2', $7^{\prime}$-dichlorodihydrofluorescein diace-
A

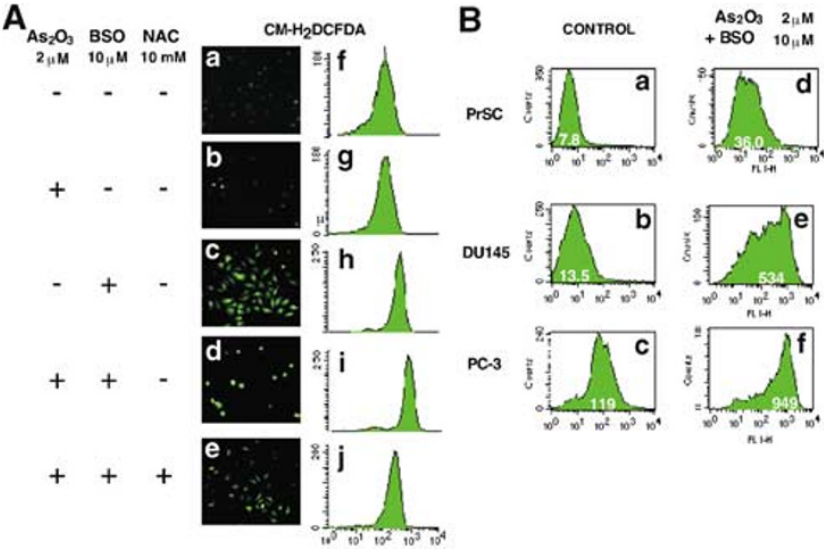

Figure 3 Correlation between the cell death sensitivity and intracellular ROS levels. (A) Detection of hydrogen peroxide, not superoxide, by fluorescent microscopy and flow cytometry. PC-3 cells treated with indicated concentrations of $\mathrm{As}_{2} \mathrm{O}_{3}, \mathrm{BSO}$, and $\mathrm{NAC}$ for $24 \mathrm{~h}$ underwent fluorescent microscopy after incubation with $\mathrm{CM}-\mathrm{H}_{2}$ DCFDA, a ROS-sensitive dye $(\mathrm{a}-\mathrm{e})$. Fluorescence was monitored by flow cytometry in PC-3 cells treated with CM- ${ }_{2}$ DCFDA (f-j). (B) Correlation of intracellular ROS levels with the sensitivity to $\mathrm{As}_{2} \mathrm{O}_{3}$ and $\mathrm{BSO}$. Basal $(a-c)$ and post-treatment $(d-f)$ levels of intracellular ROS were determined by flow cytometry using CM- $\mathrm{H}_{2}$ DCFDA in PrSC (a, d), DU145 (b, e), and PC-3 (c f) cells treated for $24 \mathrm{~h}$ with $2 \mu \mathrm{M} \mathrm{As}_{2} \mathrm{O}_{3}$ and $10 \mu \mathrm{M}$ BSO

tate), an ROS-sensitive probe in PC-3 cells. ${ }^{4}$ In contrast to the control and $2 \mu \mathrm{M} \mathrm{As}_{2} \mathrm{O}_{3}$ alone, treatment with $10 \mu \mathrm{M}$ BSO induced intense fluorescence in PC-3 cells, whereas cellular morphology remained intact (Figure $3 \mathrm{~A}$ ). The combination of $\mathrm{As}_{2} \mathrm{O}_{3}$ and $\mathrm{BSO}$ increased the fluorescent intensity further 3.5-fold and induced round cell shapes with intense fluorescence, and addition of NAC antagonized these changes and cell death (Figure $3 \mathrm{~A}$ ), indicating that these cells were undergoing apoptosis through the generation of ROS. These findings suggest that $\mathrm{As}_{2} \mathrm{O}_{3}$ plus $\mathrm{BSO}$ promotes ROS generation up to levels necessary for cell death. We further analyzed the generation of superoxide in flow cytometry using 
dihydro-ethidium. ${ }^{11}$ However, no increase was observed by either sole treatment with $\mathrm{As}_{2} \mathrm{O}_{3}$ or the combined treatment with $\mathrm{As}_{2} \mathrm{O}_{3}$ and $\mathrm{BSO}$ (data not shown). Interestingly, analysis of three representative cell lines of prostate origin showed a strong correlation between intracellular ROS levels and the sensitivity of cells to this combined treatment. PC-3 cells were most sensitive to this combination treatment, followed by DU145 and PrSC cells (Table 1), and exactly the same tendency in ROS generation under both treated or even untreated conditions were observed in these cells (Figure 3B). These findings suggested that, in cells treated with $\mathrm{As}_{2} \mathrm{O}_{3}$ plus $\mathrm{BSO}$, the degree of cell death can be determined by the levels of intracellular ROS.

\section{$\mathrm{H}_{2} \mathrm{O}_{2}$ as a mediator of cell death induced by $\mathrm{As}_{2} \mathrm{O}_{3}$ plus $\mathrm{BSO}$}

In an attempt to identify which micromolecules of ROS play an essential role in $\mathrm{As}_{2} \mathrm{O}_{3}$-induced cell death, we evaluated the effects of several ROS scavengers and antioxidant enzyme inhibitors on $\mathrm{As}_{2} \mathrm{O}_{3}$-induced cell death (Figure 4). In in vitro cytotoxic assays using PC-3 cells, neither carboxyPTIO (2-(4-carboxyphenyl)-4,4,5,5-tetramethylimidazoline-1oxyl-3-oxide), a nitrogen oxide scavenger, ${ }^{12}$ SOD, a superoxide scavenger, ${ }^{2}$ nor 2-methoxyestradiol, a specific inhibitor for SOD, ${ }^{2}$ showed any marked effect on cell death induced by $\mathrm{As}_{2} \mathrm{O}_{3}$ with or without $\mathrm{BSO}$ (data not shown). These findings suggested that neither nitrogen oxide nor superoxide plays a major role in $\mathrm{As}_{2} \mathrm{O}_{3}$-induced cell death. In contrast, catalase, a specific scavenger of hydrogen peroxide, ${ }^{13}$ showed marked inhibition of cell death induced by $\mathrm{As}_{2} \mathrm{O}_{3}$ plus $\mathrm{BSO}$. Desferoxamine, a hydroxyl radical scavenger, showed slight inhibition (Figure 4). Involvement of GSH peroxidase (GPX), another major scavenger of $\mathrm{H}_{2} \mathrm{O}_{2}$, was also indicated by the following experiment. Selenium treatment has been shown to induce GPX. ${ }^{13}$

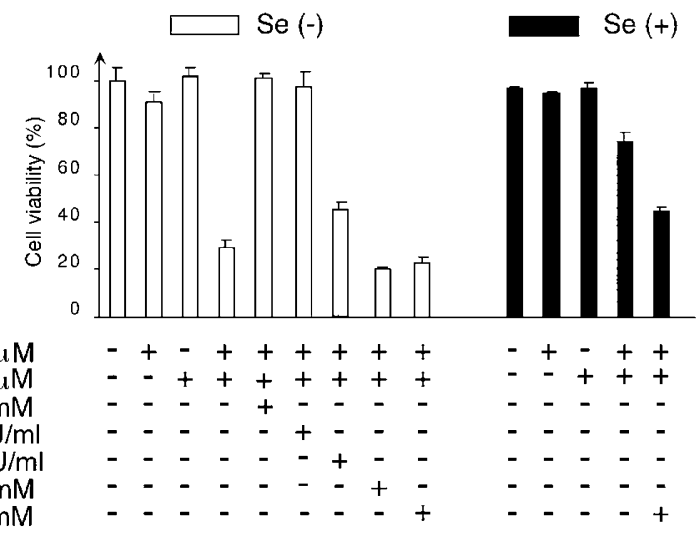

Figure $4 \quad \mathrm{H}_{2} \mathrm{O}_{2}$ as a cytotoxic mediator in $\mathrm{PC}-3$ cells treated with a combination of $\mathrm{As}_{2} \mathrm{O}_{3}$ and $\mathrm{BSO}$. PC-3 cells were incubated for $36 \mathrm{~h}$ with $\mathrm{As}_{2} \mathrm{O}_{3}$ and $\mathrm{BSO}$ following pretreatment with indicated concentrations of the drugs (open columns). Similar experiments were also conducted in PC-3 cells treated with $0.1 \mu \mathrm{M}$ sodium selenite (closed columns), which induces a 3.6-fold increase in GPX activity. After incubation, in vitro cytotoxic assay was performed using WST8. Results are given as the means \pm S.D. of three independent experiments, the value of control being $100 \%$
Indeed, 3.6-fold upregulation of GPX activity was observed after 1 month culture with $0.1 \mu \mathrm{M}$ selenium (data not shown). This treatment protected PC-3 cells from cell death induced by $\mathrm{As}_{2} \mathrm{O}_{3}$ plus $\mathrm{BSO}$ (Figure 4, black columns). In addition, both 3-amino-1H-1,2,4-triazole, a specific inhibitor for catalase, and thiomalic acid, a specific inhibitor for GPX, enhanced cell death induced by this combination (Figure 4). These findings indicate that, of $\mathrm{ROS}, \mathrm{H}_{2} \mathrm{O}_{2}$ plays a pivotal role in cell death induced by $\mathrm{As}_{2} \mathrm{O}_{3}$ plus $\mathrm{BSO}$, and raise the possibility that the level of intracellular $\mathrm{H}_{2} \mathrm{O}_{2}$ is a major determinant of cell death.

\section{Change in $\mathrm{H}_{2} \mathrm{O}_{2}$-scavenging functions in cells treated with $\mathrm{As}_{2} \mathrm{O}_{3}$ plus $\mathrm{BSO}$}

We hypothesize that overgeneration of $\mathrm{H}_{2} \mathrm{O}_{2}$ results from the dysfunction of $\mathrm{H}_{2} \mathrm{O}_{2}$-scavenging systems. To test this hypothesis biochemically, the functions of intracellular $\mathrm{H}_{2} \mathrm{O}_{2}$ scavenging systems were measured (Figure 5). In a GSH detection assay, BSO caused depletion of the total GSH levels, and $\mathrm{As}_{2} \mathrm{O}_{3}$ plus $\mathrm{BSO}$ induced further depletion of total GSH levels (Figure 5, upper panel). In PC-3 cells, combined treatment markedly reduced both catalase and GPX activities, but use of $\mathrm{As}_{2} \mathrm{O}_{3}$ or $\mathrm{BSO}$ alone did not (Figure 5, middle panel). In addition, GPX activity was affected in the same way as catalase activity (Figure 5, lower panel). These enzymatic activities, but not total GSH levels, were increased by addition of NAC, which inhibits cell death and ROS generation (Figure

\section{GSH}

Catalase
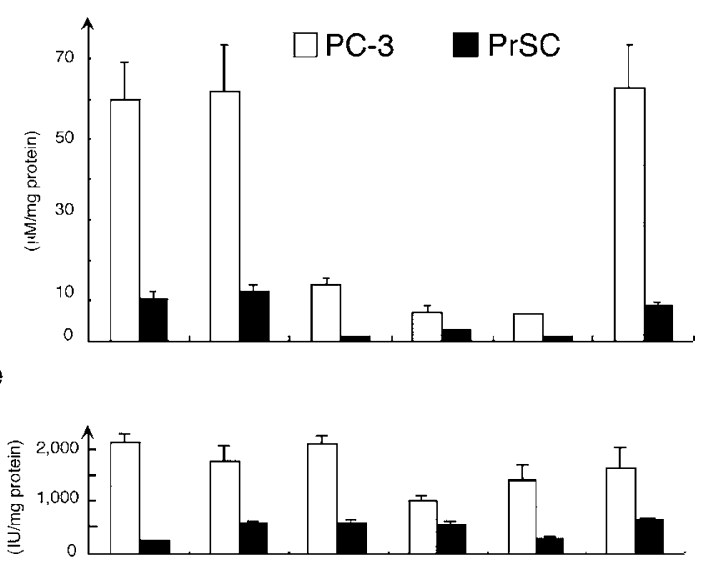

GPX

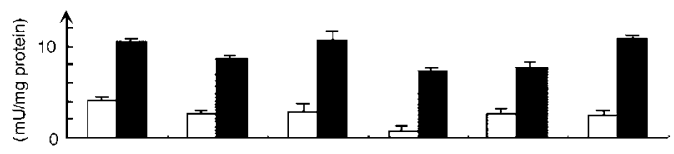

$\begin{array}{llllllll}\mathrm{As}_{2} \mathrm{O}_{3} 2 \mu \mathrm{M} & - & + & - & + & + & - \\ \mathrm{BSO} 10 \mu \mathrm{M} & - & - & + & + & + & - \\ \mathrm{NAC} 10 \mathrm{mM} & - & - & - & - & + & +\end{array}$

Figure 5 Blockade of $\mathrm{H}_{2} \mathrm{O}_{2}$-scavenging systems as a cause of overgeneration of $\mathrm{H}_{2} \mathrm{O}_{2}$. PC-3 and PrSC cells, after $24 \mathrm{~h}$ incubation with the indicated concentrations of $\mathrm{As}_{2} \mathrm{O}_{3}, \mathrm{BSO}$, and NAC underwent biochemical assays of total GSH catalase activity and GPX activity as described in Materials and Methods. Results are given as the means \pm S.D. of three independent experiments 
1B, C and Figure 3). In contrast, combined treatment elevated GSH-S-transferase (GST) activity in both PC-3 and DU145 cells (data not shown). These results indicate that in PC-3 cells $\mathrm{As}_{2} \mathrm{O}_{3}$ plus $\mathrm{BSO}$, but not $\mathrm{As}_{2} \mathrm{O}_{3}$ or $\mathrm{BSO}$ alone, can effectively inhibit $\mathrm{H}_{2} \mathrm{O}_{2}$-scavenging systems including $\mathrm{GSH}$, catalase, and GPX. Among these, decreases of catalase and/or GPX appeared to be most directly linked with $\mathrm{As}_{2} \mathrm{O}_{3} / \mathrm{BSO}$-induced cell death in PC-3 cells. Whereas in PrSC cells, which were derived from normal prostate cells and were more resistant to the combination treatment than PC-3 cells (Figure 2 and Table 1), the combination treatment induced a rather increase in catalase activity with a slight decrease in GPX activity (Figure 5). These results indicate that such differences in these enzymatic activities account for intercellular differences in the sensitivity to the combination treatment. More importantly, these findings may give the conceptual basis for a novel cancer chemotherapy; namely, blockade of $\mathrm{H}_{2} \mathrm{O}_{2}$-scavenging systems as a safe and effective strategy for cancer treatment (see Discussion).

\section{In vivo therapeutic efficacy of combined treatment with $\mathrm{As}_{2} \mathrm{O}_{3}$ and $\mathrm{BSO}$}

Finally, we applied this combination treatment to an orthotopic mouse metastasis model of androgen-independent prostate cancer. Seven weeks after the inoculation of PC-3 cells to the prostate of severe combined immunodeficient mice, combination therapy with $\mathrm{As}_{2} \mathrm{O}_{3}$ plus $\mathrm{BSO}$ induced significant growth inhibition in both primary and metastatic lesions in contrast with the control (Figure 6A). Use of $\mathrm{As}_{2} \mathrm{O}_{3}$ alone provided a dose-dependent inhibition of both primary and metastatic lesions, and addition of BSO markedly enhanced this inhibitory effect of $\mathrm{As}_{2} \mathrm{O}_{3}$ on tumor growth in both lesions (Figure 6B and $\mathrm{C}$ ). In terms of both tumor weight and number of metastases, combined treatment with $2 \mathrm{mg} / \mathrm{kg} / \mathrm{day} \mathrm{As}_{2} \mathrm{O}_{3}$ plus BSO was more effective than sole treatment with $5 \mathrm{mg} /$ $\mathrm{kg} /$ day $\mathrm{As}_{2} \mathrm{O}_{3}$. Hematoxylin and eosin staining of the primary tumor tissue did not reveal a marked difference between the saline-treated and $\mathrm{As}_{2} \mathrm{O}_{3}$-treated groups. However, in situ terminal deoxynucleotidyl transferase-mediated nucleotide
A CONTROL

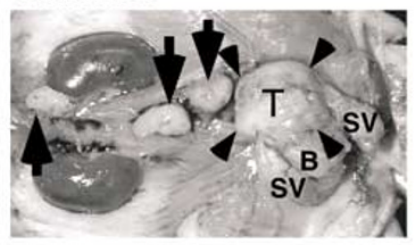

$\mathrm{As}_{2} \mathrm{O}_{3}+\mathrm{BSO}$

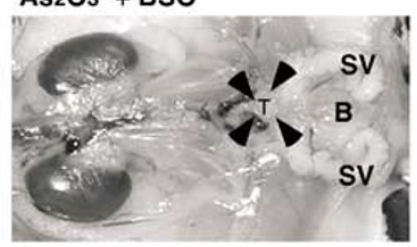

B

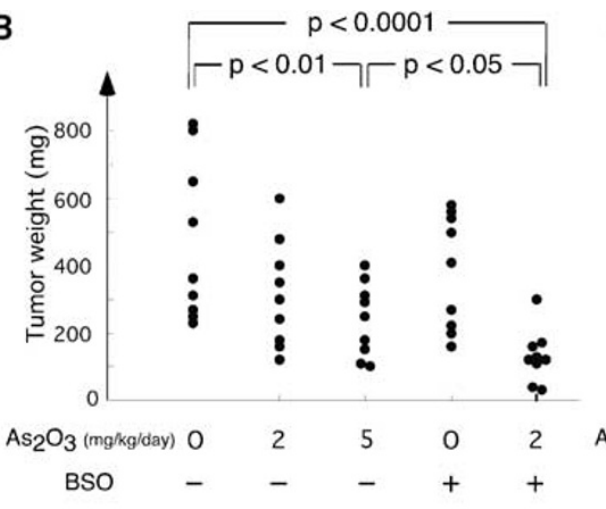

C

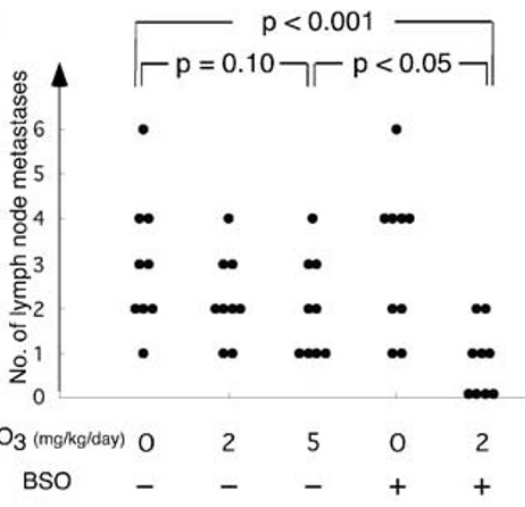

D a

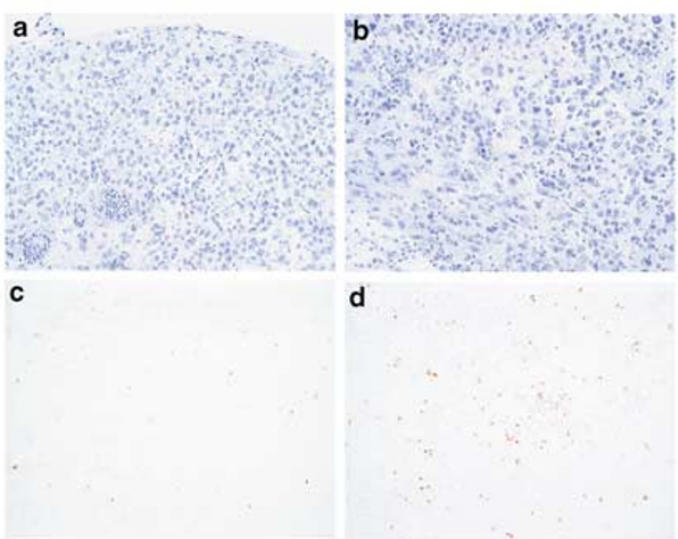

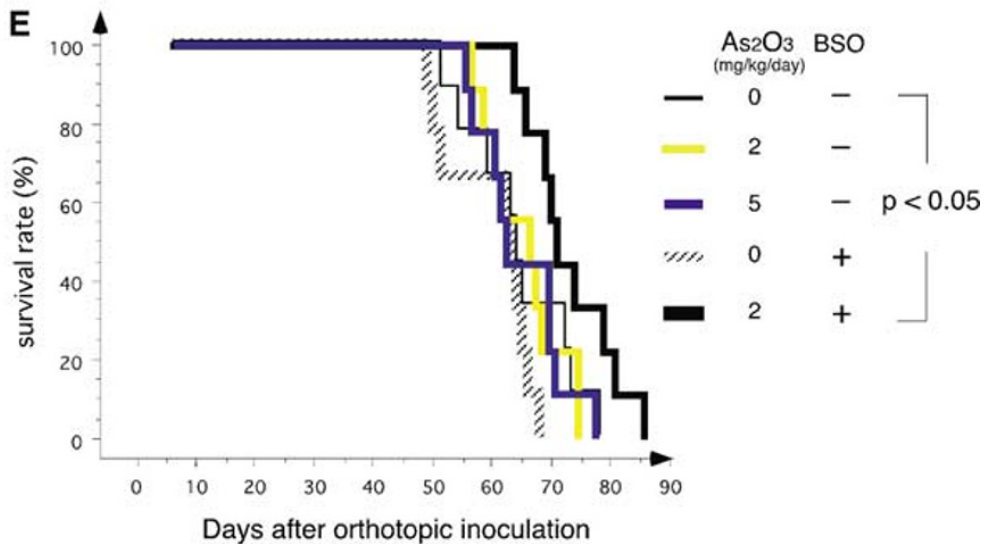

Figure 6 In vivo tumor growth inhibition and survival rates in the orthotopic mouse model of androgen-independent prostate cancer treated with $\mathrm{As}_{2} \mathrm{O}_{3}$ and $\mathrm{BSO}$. $(\mathbf{A})$ Representative cases 7 weeks after orthotopic inoculation of PC-3 cells. Seminal vesicles (SV) and the bladder (B) were exposed in the saline-treated mouse (upper panel) and mouse treated with $2 \mathrm{mg} / \mathrm{kg} /$ day $\mathrm{As}_{2} \mathrm{O}_{3}$ plus BSO (lower panel). Growth inhibition is clear both in the orthotopic tumor (black arrow-heads) and retroperitoneal lymph node metastases (black arrows) in the mouse treated with $2 \mathrm{mg} / \mathrm{kg} \mathrm{As} \mathrm{O}_{3}$ plus $\mathrm{BSO}$. (B, C) In vivo growth inhibition on primary tumors and retroperitoneal lymph node metastases in the mouse treated with saline, $\mathrm{As}_{2} \mathrm{O}_{3}$ and/ or BSO. Retroperitoneal lymph nodes larger than $0.5 \mathrm{~mm}$ in diameter were counted under a microscope, and the pathology was confirmed. There were significant differences in both lesions between the group treated with $5 \mathrm{mg} / \mathrm{kg} / \mathrm{day} \mathrm{As}_{2} \mathrm{O}_{3}$ and the group treated with $2 \mathrm{mg} /$ $\mathrm{kg} /$ day $\mathrm{As}_{2} \mathrm{O}_{3}$ plus BSO. (D) Representative histology of an orthotopic tumor formed by PC-3 cells after treatment. Hematoxylin and eosin staining (a, b) and the in situ

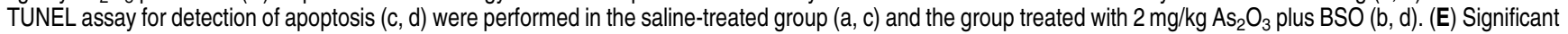
improvement of survival rate in mice treated with the combination. Survival rate was determined by using five other mouse groups following 6 -week treatment with saline, $\mathrm{As}_{2} \mathrm{O}_{3}$ and/ or BSO. A significant difference was seen between the control mice and mice treated with $2 \mathrm{mg} / \mathrm{kg} \mathrm{As} \mathrm{O}_{3}$ plus $\mathrm{BSO}(P<0.05, n=9$ for each group) 
nick-end labeling (TUNEL) analysis of primary tumors showed more cells positive for DNA fragmentation, a marker of apoptotic cell death in mice treated with the combination therapy than in the saline-treated mice (Figure 6D). Moreover, only combination therapy with $\mathrm{As}_{2} \mathrm{O}_{3}$ plus $\mathrm{BSO}$ prolonged the survival rate significantly compared with the saline-treated mice (Figure 6E). The histopathological examination showed no marked damage to the liver, lungs, or kidneys in the combination therapy group and no remarkable difference between the control and the combination therapy group (data not shown). Compared with the saline-treated group, only the group with $5 \mathrm{mg} / \mathrm{kg} \quad \mathrm{As}_{2} \mathrm{O}_{3}$ alone showed a significant decrease in the hemoglobin level (mean 16.3 versus $13.8 \mathrm{~g} /$ dl, $P<0.05)$. There was no significant difference between groups in the number of white blood cells and platelets (data not shown). Slight loss in body weight was observed during the treatment period ( $9 \sim 15 \%$ decrease from the base line), but it was not significant among treatment groups. These in vivo findings indicate that combination with $\mathrm{As}_{2} \mathrm{O}_{3}$ plus $\mathrm{BSO}$ is superior to $\mathrm{As}_{2} \mathrm{O}_{3}$ alone in all the aspects examined: growth inhibition, survival rate, and absence of side effects.

\section{Discussion}

The first goal of this study was to develop $\mathrm{As}_{2} \mathrm{O}_{3}$-based effective combination chemotherapy against advanced solid tumors, especially of prostate origin. Using in vitro assays, combination treatment with $\mathrm{BSO}$ sensitized $\mathrm{As}_{2} \mathrm{O}_{3}$-induced cytotoxicity in all investigated cancer cell lines including several so-called drug-resistant lines at clinically achievable concentrations of both drugs (Figure 1 and Table 1). Strikingly, this combination clearly showed more cytotoxicity to cancer cells in in vitro assays compared with normal cells (Figure 2). In in vivo studies using a mouse orthotopic metastasis model, combination treatment with BSO enhanced the therapeutic effects of $\mathrm{As}_{2} \mathrm{O}_{3}$ in tumor growth inhibition and survival rate with few side effects (Figure 6). Our findings demonstrate the combination of $\mathrm{As}_{2} \mathrm{O}_{3}$ and $\mathrm{BSO}$ as a clinically promising approach in the treatment of advanced solid tumors. Another goal of this study was to clarify the molecular mechanism of this combination treatment for the development of more effective combination chemotherapy. The degree of cell death correlated with the intracellular levels of ROS (Figure 3). Of ROS, $\mathrm{H}_{2} \mathrm{O}_{2}$ was clearly shown as a major mediator of cell death induced by this combination treatment (Figure 4). The degree of cell death apparently correlated with the intracellular levels of $\mathrm{H}_{2} \mathrm{O}_{2}$, which was generated by the blockade of $\mathrm{H}_{2} \mathrm{O}_{2}$-scavenging system (Figures 3 and 5). These findings imply that more effective $\mathrm{As}_{2} \mathrm{O}_{3}$-based combination chemotherapy can be developed through the analysis of these molecular targets.

Based on our previous study showing ROS as a cytotoxic mediator of $\mathrm{As}_{2} \mathrm{O}_{3}$-induced cell death, ${ }^{4}$ our present study demonstrated $\mathrm{BSO}$ as a potent sensitizer of $\mathrm{As}_{2} \mathrm{O}_{3}$-based combination chemotherapy. BSO was originally used as a sensitizer of L-PAM, an alkylating anticancer agent. ${ }^{7}$ Subsequent clinical trials with L-PAM plus BSO, however, did not show therapeutic effects on advanced solid tumors. ${ }^{8}$ Our in vitro growth inhibition assays provide experimental evidence for this failure in clinical trials. In prostate cancer cell lines treated with $10 \mu \mathrm{MBSO}$, the degree of sensitization was only a 1.4-1.6-fold decrease in $\mathrm{IC}_{50}$ values of L-PAM. Remarkably, a 10.7-12.2-fold decrease was observed in $\mathrm{IC}_{50}$ values of $\mathrm{As}_{2} \mathrm{O}_{3}$ (Table 1). These results suggest that, for the clinical use of $\mathrm{BSO}$, combination with $\mathrm{As}_{2} \mathrm{O}_{3}$ is more promising than that with L-PAM and is currently most promising.

The sensitization by BSO was found in all of investigated solid tumor cell lines, both drug-sensitive and even drugresistant (Table 1). Resistance against anticancer drugs are divided into two categories based on the involvement of $\mathrm{P}$ glycoprotein, which is a key molecule in drug resistance to DOX, but not to CDDP. ${ }^{9}$ Both the drug-resistant cell lines we tested, ACHN-CDDP resistant to CDDP and 5637-DR50 resistant to $\mathrm{DOX}$, showed mild crossresistance to $\mathrm{As}_{2} \mathrm{O}_{3}$. This finding implies that sole $\mathrm{As}_{2} \mathrm{O}_{3}$ treatment might be ineffective on so-called drug-resistant advanced cancers due to the crossresistance, as other investigator reported. ${ }^{14}$ However, the combination of $\mathrm{As}_{2} \mathrm{O}_{3}$ plus $\mathrm{BSO}$ succeeded in overcoming this crossresistance at clinically achievable concentrations of these drugs (Table 1). Furthermore, the combination of $\mathrm{As}_{2} \mathrm{O}_{3}$ plus BSO sensitized normal and cancer cells to $\mathrm{As}_{2} \mathrm{O}_{3}$ cytotoxicity (Table 1 and Figure 1 ). The sensitization itself was not specific to cancer cells (Figure 2), but this combination realized more cytotoxicity to cancer cells with less damage to normal cells at clinically obtainable concentrations of these two drugs, whereas sole $\mathrm{As}_{2} \mathrm{O}_{3}$ treatment could not (Figure 2). All these results suggest that the sensitization with $\mathrm{BSO}$ on $\mathrm{As}_{2} \mathrm{O}_{3}$ efficacy may be a clinically promising approach with less side effects in all advanced solid tumors.

Further analysis demonstrated $\mathrm{H}_{2} \mathrm{O}_{2}$ as a major cytotoxic molecule of ROS in $\mathrm{As}_{2} \mathrm{O}_{3}$-induced cell death (Figure 4). $\mathrm{H}_{2} \mathrm{O}_{2}$ is known as a cell-death mediator in diverse kinds of cell death including that induced by tumor necrosis factor- $\alpha$, UV irradiation, and other anticancer drugs. ${ }^{15-17}$ In the case of cell death of leukemia cells by $\mathrm{As}_{2} \mathrm{O}_{3}$, involvement of $\mathrm{H}_{2} \mathrm{O}_{2}$ has been also demonstrated. ${ }^{13}$ Flow cytometric analysis showed that BSO alone induced certain amounts of ROS without cell death, whereas addition of $\mathrm{As}_{2} \mathrm{O}_{3}$ generated a greater amount of ROS, followed by cell death (Figure 3). At both treated and nontreated phases, the intracellular ROS levels correlated well with the sensitivity to the treatment with $\mathrm{As}_{2} \mathrm{O}_{3}$ plus $\mathrm{BSO}$ (Figure 3). These findings lead us to propose a novel therapeutic concept, 'the blockade of $\mathrm{H}_{2} \mathrm{O}_{2}$-scavenging systems'. In short, the majority of cells, either of normal or cancer cell origin, seem to tolerate $\mathrm{BSO}$ - or even $\mathrm{As}_{2} \mathrm{O}_{3}$ induced $\mathrm{H}_{2} \mathrm{O}_{2}$, since these cells possess enough ability to scavenge such $\mathrm{H}_{2} \mathrm{O}_{2}$ even after the sole exposure of $\mathrm{BSO}$ or $\mathrm{As}_{2} \mathrm{O}_{3}$ (Figure 5), which we referred to here as ${ }^{\prime} \mathrm{H}_{2} \mathrm{O}_{2}$ scavenging systems'. However, the exposure of $\mathrm{As}_{2} \mathrm{O}_{3}$ plus BSO makes such $\mathrm{H}_{2} \mathrm{O}_{2}$-scavenging systems break down, which is typically observed as the decrease of GSH amount as well as the decrease of catalase and GPX activities in cancerous PC-3 cells (Figure 5). These cells can no longer scavenge intracellular ROS and are thus killed by continuous exposure of ROS generated by $\mathrm{As}_{2} \mathrm{O}_{3}$ plus $\mathrm{BSO}$. In other words, the innate capacity of $\mathrm{H}_{2} \mathrm{O}_{2}$-scavenging systems could determine sensitivity to the treatment with $\mathrm{As}_{2} \mathrm{O}_{3}$ plus $\mathrm{BSO}$. Between cancer and normal cells, the difference in the capacity of these $\mathrm{H}_{2} \mathrm{O}_{2}$-scavenging systems appears to 
reflect the difference in sensitivity to the treatment with $\mathrm{As}_{2} \mathrm{O}_{3}$ plus BSO (Figure 5). Catalase and GPX activities of PrSC cells, which are originated from normal prostate, showed almost complete resistance to $\mathrm{As}_{2} \mathrm{O}_{3}$ plus $\mathrm{BSO}$ treatment. We believe that these results can account for the difference in sensitivity between normal and cancer cells to the treatment with $\mathrm{As}_{2} \mathrm{O}_{3}$ plus $\mathrm{BSO}$. Molecular basis that brings this difference, however, remain to be clarified (see below).

Currently, $\mathrm{As}_{2} \mathrm{O}_{3}$ induces complete remission in most cases of relapsed acute promyelocytic leukemia with mild side effects. ${ }^{3}$ BSO has already warranted its safety in clinical use. ${ }^{7,8}$ Owing to their immediate feasibility for clinical use, the combination chemotherapy of $\mathrm{As}_{2} \mathrm{O}_{3}$ plus $\mathrm{BSO}$ immediately allows many clinicians to examine clinical efficacies. Several in vitro experiments have already examined the efficacy of the combined treatment with $\mathrm{As}_{2} \mathrm{O}_{3}$ plus $\mathrm{BSO}$, although the approach is experimental, not therapeutic. ${ }^{13,18,19}$ However, to our knowledge, this is the first in vivo study that investigated the combination therapy with $\mathrm{As}_{2} \mathrm{O}_{3}$ plus $\mathrm{BSO}$. Our in vivo study showed that this combination induced tumor growth inhibition in both primary and metastatic lesions, and that this combination therapy prolonged survival rate significantly compared with the control or $\mathrm{As}_{2} \mathrm{O}_{3}$ treatment alone. In addition to in vitro cytotoxicity to cancer cells, our in vivo study clearly showed that this combination chemotherapy can be carried out safely without any anemia or serious toxicity to major organs. Moderate body weight loss in the treatment groups seems clinically manageable. Beside apparent minimal side effects in our mouse models, this combination therapy has a unique advantage of preventing side effects. Local administration of antioxidants like NAC could protect major organs from unexpected damage. ${ }^{20}$ All these results provide experimental evidence that supports clinical use of combined therapy with $\mathrm{As}_{2} \mathrm{O}_{3}$ plus BSO.

The origin of cancer selectivity achieved by the combination therapy remains to be deciphered. This might be explained by the difference in a cell's dependence on scavenging systems. Cancer cells may be highly dependent on catalase and GPX systems for scavenging radicals in order to meet the requirement of rapid growth and vigorous metabolism. ${ }^{21}$ Although extraordinarily strong antioxidant defense systems exist in some leukemia cells and confer them resistant to even the combination of $\mathrm{As}_{2} \mathrm{O}_{3}$ plus $\mathrm{BSO},{ }^{21}$ an alternative pharmacological inhibitor for one antioxidant enzyme was proposed by Huang et al. ${ }^{2}$ for such leukemia cells. The development of novel combinations of ROS generators with these specific inhibitors of radical scavenging systems, based on our approach, will provide more effective combination anticancer therapy in the near future. The effectiveness of this type of therapy can be described as a 'Trip and Hit' effect: the $\mathrm{H}_{2} \mathrm{O}_{2}$-scavenge systems are first tripped and broken by $\mathrm{As}_{2} \mathrm{O}_{3}$ plus $\mathrm{BSO}$ and, then or almost simultaneously, the cancer cells are effectively hit and killed by resultantly generated strong $\mathrm{H}_{2} \mathrm{O}_{2}$.

In conclusion, the combination chemotherapy with $\mathrm{As}_{2} \mathrm{O}_{3}$ plus $\mathrm{BSO}$ can be a valid model for blockade of $\mathrm{H}_{2} \mathrm{O}_{2}$ scavenging systems, and can be expected as a promising approach in the treatment of advanced solid tumors including relapsed drug-resistant ones. Future clinical studies are awaited to examine the therapeutic effect of this combination chemotherapy.

\section{Materials and Methods}

\section{Reagents}

$\mathrm{As}_{2} \mathrm{O}_{3}, \mathrm{BSO}, \mathrm{CDDP}, \mathrm{DOX}$, L-PAM, Hoechst 33342, Rhodamine 123 propidium iodide, and cycloheximide were purchased from Sigma (St. Louis, MO, USA). $\mathrm{As}_{2} \mathrm{O}_{3}$ was prepared as reported previously. ${ }^{4} \mathrm{NAC}$ DTT, SOD, desferoxamine, catalase, 3-amino-1H-1,2,4-triazole, thiomalic acid, and sodium selenite were obtained from Nacalai tesque (Kyoto, Japan). Carboxy-PTIO was purchased from Dojindo (Kumamoto, Japan).

\section{Cell culture}

Cells were cultured as reported previously. ${ }^{1,4}$ The origins of the cell lines were as follows: SC115, mouse mammary carcinoma; Lewis lung carcinoma (LLC), mouse lung carcinoma; HCT15, human colon carcinoma; HeLa, human cervix cancer; PrEC, normal prostate epithelium; PrSC, normal prostate stromal cells. LLC cells were maintained in DMEM with $10 \%$ fetal calf serum, HCT15 cells in RPMI1640 with $10 \%$ fetal calf serum. PrEC and PrSC cells were purchased from Clonetics (San Diego, CA, USA). According to manufacturer's instructions, PrEC cells were maintained in prostate epithelial growth medium containing $0.4 \%$ bovine pituitary extract, $5 \mu \mathrm{g} / \mathrm{ml}$ hydrocortisone, $0.5 \mathrm{ng} / \mathrm{ml}$ human epithelial growth factor, $0.5 \mathrm{ng} / \mathrm{ml}$ epinephrine, $10 \mu \mathrm{g} / \mathrm{ml}$ transferrin, $5 \mu \mathrm{g} / \mathrm{ml}$ insulin, $0.1 \mathrm{ng} / \mathrm{ml}$ retinoic acid, and $6.5 \mathrm{ng} / \mathrm{ml}$ tri-iodothyronine. PrSC cells were maintained in RPMI 1640 with $10 \%$ fetal calf serum. 5637-DR50 cells resistant to doxorubicin, an anthracycline anticancer agent, and $\mathrm{ACHN}$ CDDP cells resistant to CDDP, a platinum anticancer agent, were established from parental cells, 5637, a bladder cancer cell line, and ACHN, a kidney cancer cell line, respectively, as reported previously. ${ }^{9,10}$ PC-3 cells were pretreated with $100 \mathrm{nmol} / /$ sodium selenite for 30 days to enhance GPX activity. $^{13}$

\section{Assays for cell growth, cytotoxicity, and apoptosis detection}

Cell growth assays using WST-8 (2-(2-methoxy-4-nitrophenyl)-3-(4nitrophenyl)-5-(2,4-disulfophenyl)-2H-tetrazolium monosodium salt), modified from the MTT assay, were performed and $\mathrm{IC}_{50}$ values were determined as previously reported. ${ }^{4}$ Briefly, $2.5 \times 10^{3}$ cells were plated per well in $100 \mu$ l of medium in 96-well microtiter plates. Cells were grown for $24 \mathrm{~h}$, after which various concentrations of the test compounds were added. After an additional $48 \mathrm{~h}$ of incubation, the medium was aspirated, and WST-8 solution was added. After incubation at $37^{\circ} \mathrm{C}$, the optical density of each well was determined in a microplate reader by the absorbance spectrophotometry at the wavelength of $450 \mathrm{~nm}$. The assay gave an absorbance that correlated linearly with the number of cells and was not affected by $\mathrm{As}_{2} \mathrm{O}_{3}$ itself (data not shown). Cell growth was expressed as a percent of the absorbance in the vehicle-treated control wells. Dose-response curves were drawn, and $\mathrm{IC}_{50}$ value, the concentration that inhibits $50 \%$ of the growth of control cells, was calculated by PRISM (GraphPad, San Diego, CA, USA). A cytotoxic assay was also conducted by adding WST-8 to cells in 96-well plates. In all, $1.5 \times 10^{4}$ cells/well were plated and various concentrations of the test agents were added $24 \mathrm{~h}$ after plating. After an additional incubation for indicated hours, cell viability was measured and is expressed as a percent of the absorbance in the vehicle-treated control wells. ROS-related 
compounds were added $2 \mathrm{~h}$ before the addition of $\mathrm{As}_{2} \mathrm{O}_{3}$ in experiments using them at the concentrations that alone showed no significant effects. Apoptosis was determined as previously reported ${ }^{4}$ by fluorescent microscopy using Hoechst 33342 for nuclear morphology and rhodamine 123 for mitochondria transmembrane potential, and by flow cytometry using propidium iodide.

\section{Assays for intracellular superoxide, ROS, and total GSH levels}

Intracellular superoxide levels were determined using $5 \mu \mathrm{M}$ dihydroethidium (Molecular Probes, Eugene, OR, USA), which is permeable and is oxidized to ethidium by superoxide anions. Ethidium fluorescence was monitored by FACScan with excitation at $488 \mathrm{~nm}$ and emission at $605 \mathrm{~nm}^{11}$ Intracellular accumulation of ROS was monitored with flow cytometry using $\mathrm{CM}-\mathrm{H}_{2} \mathrm{DCFDA}$ (Molecular Probes, Eugene, OR, USA) as reported previously. ${ }^{4}$ Concentrations of intracellular total GSH, which comprised reduced GSH and oxidized GSH, were determined using GSH reductase-DTNB (5,5'-dithiobis (2-nitrobenzoic acid)) recycling method as reported previously. ${ }^{9}$

\section{Assays for determination of antioxidant enzyme activities}

Subconfluent PrSC, PC-3, and DU145 cells were grown in cell culture medium with various concentrations of compounds. Cells were incubated for the period indicated, harvested, washed twice with PBS, resuspend with PBS, sonicated for $5 \mathrm{~s}$, centrifuged at $12000 \mathrm{~g}$ for $30 \mathrm{~min}$, and supernatants were subjected to enzyme assays. Intracellular catalase activity was measured by monitoring the decrease in absorbance of $\mathrm{H}_{2} \mathrm{O}_{2}$ at $240 \mathrm{~nm}$ as it is degraded. ${ }^{13}$ Intracellular activities of GPX and GST were measured as previously reported with minor modifications. ${ }^{9}$

\section{In vivo mouse studies}

The in vivo therapeutic effect of $\mathrm{As}_{2} \mathrm{O}_{3}$ plus $\mathrm{BSO}$ was evaluated in an orthotopic prostatic mouse model as reported elsewhere. ${ }^{4,22}$ In this model, inoculation of PC-3 cells to the mouse prostate provides a high incidence of metastasis to the lymph nodes. Mice were divided into five subgroups according to the daily dose: Group $1(n=9)$, saline alone i.p.; Group 2 $(n=9), 2 \mathrm{mg} / \mathrm{kg} \mathrm{As}{ }_{2} \mathrm{O}_{3}$ i.p.; Group $3(n=9), 5 \mathrm{mg} / \mathrm{kg} \mathrm{As} \mathrm{O}_{3}$ i.p.; Group 4 $(n=9), 5 \mathrm{mg} / \mathrm{kg}$ BSO diluted in PBS, i.p. $+15 \mathrm{mM} \mathrm{BSO}$ diluted in drinking water and given orally; Group $5(n=9), 2 \mathrm{mg} / \mathrm{kg} \mathrm{As}{ }_{2} \mathrm{O}_{3}$ i.p., $5 \mathrm{mg} / \mathrm{kg}$ BSO diluted in PBS, i.p. $+15 \mathrm{mM}$ BSO diluted in drinking water and given orally. Five other mouse groups were also prepared for the determination of survival rate. The drug was administrated 1 week after surgery and continued daily for 6 weeks. In Group 5, intraperitoneal administration of $\mathrm{As}_{2} \mathrm{O}_{3}$ was decreased from 2 to $1 \mathrm{mg} / \mathrm{kg} /$ day from the fourth week of administration. At 7 weeks after inoculation, the mice were killed using deep anesthesia. Evaluations of tumor growth and side effects were carried out as reported previously. 4,22

\section{Statistics}

An analysis of variance and Fisher's PLSD test for post hoc comparisons were used for the statistical analyses between groups. Survival rate was determined by Wilcoxon test and $P$-values of less than 0.05 were considered significant.

\section{Acknowledgements}

This study was supported in part by Grants 14370514 (to YK), 12215156 (to AK) from the Ministry of Education, Science, Culture and Sports, Japan, 11-10 (to YK) from The Ministry of Health and Welfare of Japan, and a grant from the Japan Society for the Promotion of Science for Young Scientists (to HM). We thank Prof. T Serikawa, O Fujii, and other staff members of Institute of Laboratory Animals, Kyoto University, Graduate School of Medicine, for careful animal maintenance, M Sugimoto for secretarial assistance in the preparation of this manuscript, C Sayo, A Yamaguchi, T Matsushita, and I Fujiwara for their technical assistance, Cell Resource Center for Biomedical Research, Institute of Development, Aging and Cancer, Tohoku University and Dr. K Shimizu, Department of Gastroenterological Surgery, Kyoto University Graduate School of Medicine, for providing HCT-15 cells. We thank the National Cancer Institute, Center for Cancer Research Fellows Editorial Board for their critical reading of the manuscript.

\section{References}

1. Segawa T, Takebayashi H, Kakehi Y, Yoshida O, Narumiya S and Kakizuka A (1998) Prostate-specific amplification of expanded polyglutamine expression: a novel approach for cancer gene therapy. Cancer Res. 58: 2282-2287

2. Huang P, Feng L, Oldham EA, Keating MJ and Plunkett W (2000) Superoxide dismutase as a target for the selective killing of cancer cells. Nature 407: 390395

3. Shen ZX, Chen GQ, Ni JH, Li XS, Xiong SM, Qiu QY, Zhu J, Tang W, Sun GL, Yang KQ, Chen Y, Zhou L, Fang ZW, Wang YT, Ma J, Zhang P, Zhang TD, Chen SJ, Chen Z and Wang ZY (1997) Use of arsenic trioxide $\left(\mathrm{As}_{2} \mathrm{O}_{3}\right)$ in the treatment of acute promyelocytic leukemia (APL): II. Clinical efficacy and pharmacokinetics in relapsed patients. Blood 89: 3354-3360

4. Maeda H, Hori S, Nishitoh H, Ichijo H, Ogawa O, Kakehi $Y$ and Kakizuka A (2001) Tumor growth inhibition by arsenic trioxide in the orthotopic metastasis model of androgen-independent prostate cancer. Cancer Res. 61: 5432-5440

5. Chen GQ, Shi XG, Tang W, Xiong SM, Zhu J, Cai X, Han ZG, Ni JH, Shi GY, Jia PM, Liu MM, He KL, Niu C, Ma J, Zhang P, Zhang TD, Paul P, Naoe T, Kitamura K, Miller W, Waxman S, Wang ZY, de The H, Chen SJ and Chen Z (1997) Use of arsenic trioxide $\left(\mathrm{As}_{2} \mathrm{O}_{3}\right)$ in the treatment of acute promyelocytic leukemia (APL): I. $\mathrm{As}_{2} \mathrm{O}_{3}$ exerts dose-dependent dual effects on APL cells. Blood 89: 3345-3353

6. Halliwell B and Gutteridge JM (1990) Role of free radicals and catalytic metal ions in human disease: an overview. Methods Enzymol. 186: 1-85

7. Bailey HH (1998) L-S,R-buthionine sulfoximine: historical development and clinical issues. Chem. Biol. Interact. 111-112: 239-254

8. Bailey HH, Ripple G, Tutsch KD, Arzoomanian RZ, Alberti D, Feierabend C, Mahvi D, Schink J, Pomplun M, Mulcahy RT and Wilding G (1997) Phase I study of continuous-infusion L-S, $R$-buthionine sulfoximine with intravenous melphalan. J. Natl. Cancer Inst. 89: 1789-1796

9. Kim WJ, Kakehi Y and Yoshida O (1997) Multifactorial involvement of multidrug resistance-associated protein, DNA topoisomerase II and glutathione/ glutathione-S-transferase in nonP-glycoprotein-mediated multidrug resistance in human bladder cancer cells. Int. J. Urol. 4: 583-590

10. Nishii Y, Morishima M, Kakehi Y, Umehara K, Kioka N, Terano Y, Amachi T and Ueda K (2000) CROP/LuC7A, a novel serine/arginine-rich nuclear protein, isolated from cisplatin-resistant cell line. FEBS Lett. 465: 153-156

11. Sharikabad MN, Hagelin EM, Hagberg IA, Lyberg T and Brors $O$ (2000) Effect of calcium on reactive oxygen species in isolated rat cardiomyocytes during hypoxia and reoxygenation. J. Mol. Cell Cardiol. 32: 441-452

12. Maeda H, Akaike T, Yoshida M, Sato K and Noguchi Y (1995) A new nitric oxide scavenger, imidazolineoxyl $\mathrm{N}$-oxide derivative, and its effects in pathophysiology and microbiology. Curr. Top. Microbiol. Immunol. 196: 37-50

13. Jing Y, Dai J, Chalmers-Redman RM, Tatton WG and Waxman S (1999) Arsenic trioxide selectively induces acute promyelocytic leukemia cell apoptosis via a hydrogen peroxide-dependent pathway. Blood 94: 2102-2111 
14. Liu J, Chen H, Miller DS, Saavedra JE, Keefer LK, Johnson DR, Klaassen CD and Waalkes MP (2001) Overexpression of glutathione S-transferase II and multidrug resistance transport proteins is associated with acquired tolerance to inorganic arsenic. Mol. Pharmacol. 60: 302-309

15. Bohler T, Waiser J, Hepburn H, Gaedeke J, Lehmann C, Hambach P, Budde K and Neumayer HH (2000) TNF-alpha and IL-1alpha induce apoptosis in subconfluent rat mesangial cells. Evidence for the involvement of hydrogen peroxide and lipid peroxidation as second messengers. Cytokine 12: 986-991

16. Komatsu M, Takahashi T, Abe T, Takahashi I, Ida H and Takada G (2001) Evidence for the association of ultraviolet- $\mathrm{C}$ and $\mathrm{H}_{2} \mathrm{O}_{2}$-induced apoptosis with acid sphingomyelinase activation. Biochim. Biophys. Acta 1533: 47-54

17. Bauer $G$ (2000) Reactive oxygen and nitrogen species: efficient, selective, and interactive signals during intercellular induction of apoptosis. Anticancer Res. 20: 4115-4139

18. Yang CH, Kuo ML, Chen JC and Chen YC (1999) Arsenic trioxide sensitivity is associated with low level of glutathione in cancer cells. Br. J. Cancer 81 796-799
19. Kito M, Akao Y, Ohishi N, Yagi $K$ and Nozawa $Y$ (2002) Arsenic trioxideinduced apoptosis and its enhancement by buthionine sulfoximine in hepatocellular carcinoma cell lines. Biochem. Biophys. Res. Commun. 291: 861-867

20. Neuwelt EA, Pagel MA, Hasler BP, Deloughery TG and Muldoon LL (2001) Therapeutic efficacy of aortic administration of $\mathrm{N}$-acetylcysteine as a chemoprotectant against bone marrow toxicity after intracarotid administration of alkylators, with or without glutathione depletion in a rat model. Cancer Res. 61: 7868-7874

21. Jung K, Seidel B, Rudolph B, Lein M, Cronauer MV, Henke W, Hampel G, Schnorr D and Loening SA (1997) Antioxidant enzymes in malignant prostate cell lines and in primary cultured prostatic cells. Free Radic. Biol. Med. 23: 127133

22. Maeda H, Segawa T, Kamoto T, Yoshida H, Kakizuka A, Ogawa $\mathrm{O}$ and Kakehi $Y$ (2000) Rapid detection of candidate metastatic foci in the orthotopic inoculation model of androgen-sensitive prostate cancer cells introduced with green fluorescent protein. Prostate 45: 335-340 